\title{
WASTEWATER FROM SWINE FARMING IN THE GROWTH AND NUTRITION OF KHAYA SENEGALENSIS (DESR.) A JUSS SEEDLINGS
}

\author{
ÁGUA RESIDUÁRIA DA SUINOCULTURA NO CRESCIMENTO E NUTRIÇÃO \\ DE MUDAS DE KHAYA SENEGALENSIS (DESR.) A JUSS
}

\section{Emanuel França ARAÚJO'; ${ }^{1}$ Adriana Miranda de Santana ARAUCO²; Bruna Anair Souto DIAS ${ }^{3}$; Julian Júnio de Jesus LACERDA²; Cácio Luiz BOECHAT²; Dayara Lins PORTO ${ }^{4}$, Luis Ricardo Romero ARAUCO ${ }^{5}$}

1. Post-graduate, Federal University of Espírito Santo, Department of Forest and Wood Sciences, Campus Jerônimo Monteiro, State of Espírito Santo, Brazil. emanuelfa.bj@ hotmail.com; 2. Professor of the Federal University of Piauí, Campus Professor Cinobelina Elvas UFPI / CPCE, Course of Agronomic Engineering, Bom Jesus, Piauí State, Brazil; 3. Professor at the Federal University of Piauí, Campus Professor Cinobelina Elvas - UFPI / CPCE, Forest Engineering Course, Bom Jesus, State of Piauí, Brazil; 4. Graduate of the Federal University of Piauí, Postgraduate Program in Agronomy: Soils and Plant Nutrition, Campus Professor Cinobelina Elvas, Bom Jesus, Piauí State, Brazil; 5 Professor of the Federal University of Piauí, Campus Professor Cinobelina Elvas - UFPI / CPCE, Course of Zootecnia, Bom Jesus, Piauí State, Brazil.

\begin{abstract}
This study evaluated the use of wastewater from swine farming in the growth and nutritional balance of Khaya senegalensis (Desr.) A. Juss. (African mahogany) seedlings. The experiment was setup in a shade house on the Professor Cinobelina Elvas Campus of the Federal University of Piauí, in Bom Jesus, in the State of Piauí, Brazil. The experimental design was completely randomised, with five concentrations of swine farm wastewater (SFW) $(0,25,50,75$ and 100\%) added to the irrigation water. The growth and nutritional balance of the seedlings were evaluated 100 days after sowing, by measuring shoot height (H), stem diameter (SD), number of leaves (NL), total chlorophyll (TC), leaf area (LA), shoot dry weight (SDW) and root dry weight (RDW), and by calculating the total dry weight (TDW), leaf (LBA), stem (SBA), and root (RBA) biomass allocation, Dickson Quality Index (DQI) and average Nutritional Balance Index (NBIm). It was found that $K$. senegalensis seedlings responded to the SFW, showing the best results for growth and nutritional balance at concentrations of around $50 \%$.
\end{abstract}

KEYWORDS: Swine manure. African mahogany. Biomass allocation. Superior-quality wood. DRIS.

\section{INTRODUCTION}

Global production of waste (liquid and solid waste) from swine farms is growing together with global demand for food and protein from animals. In the year of 2008, over 90 million metric tons of pork were produced globally. In Brazil over 3.3 million metric tons were produced in 2015. Nearly 60 percent of pig production in Brazil is concentrated in the three southern states, Santa Catarina, Paraná and Rio Grande do Sul (USDA, 2008; 2015).

Swine waste generated from pigdomesticating industry is considered a primary source for fresh water pollution around the world. Although many treatment systems have been proposed, the wastewater still is high in inorganic elements, which cause deterioration of water resources and consequently environmental changes (CHEUNBARN; PEERAPORNPISAL，2010). In Brazil, states of south region produce approximately 8.6 liters of waste per animal-day, depending on the productive phase (PEGORARO et al., 2014).
Generally, wastewater presents high content of organic matter and other nutrients, especially nitrogen and phosphorus, but it is necessary to characterize itr chemically to know its potential impacts on the environment. Furthermore, wastewater is capable of providing improvements in soil physical, chemical and biological properties, providing nutrients for crop and still bringing to the producer productivity increase and cost reduction (SCHERER et al., 2007).

Therefore, an ecofriendly alternative to wastewater is its use as nutrient source in vegetation fertilization, enhancing soil chemical attributes and promoting nutrient cycling. This practice allows the farmer to minimize the costs with conventional fertilizers and provides an alternative to the raw discharge of residues generated from extensive poultry, beef and pork production, allowing soil and plants to be used as filters (CABRAL et al., 2014; PEgoraro et al., 2014; ROSA et al., 2017a).

Several studies have evaluated the effects of wastewater use on agricultural crops (GÓMEZGARRIDO et al., 2014; PASSARIN et al., 2016; 
ROSA et al., 2017a), and on changes in soil chemical, physical and biological attributes (TESSARO et al., 2013; Brooks et al., 2014; CABRAL et al., 2014 CASTALDELLI et al., 2015; OLIVEIRA et al., 2015; Pereira et al., 2016; MOURA et al., 2016; ROSA et al., 2017b; PACHECO et al., 2017). However, there is still little information on the use of wastewater in forest production. Studies are also lacking in the growth and quality of seedlings of Khaya senegalensis.

Khaya senegalensis is a naturally occurring forest species in several African countries, with wood of great commercial interest for use both in furniture manufacturing and interior decoration (Lamprecht, 1990). Besides the purpose of logging, the species has therapeutic value, such astreatment of rheumatoid arthritis, syphilis, leprosy (FALODUN; OBASUYI, 2009; IDU et al., 2014), of microbial infections, autoimmune inflammatory diseases and some cancers (RABADEAUX et al., 2017), diabetes (KOLAWOLE et al., 2012), Leishmaniasis (KAYSER; ABREU, 2001), dermatitis and other skin diseases, diarrhoea and dysentery, fever, jaundice, malaria and sexuallytransmitted diseases, and as an anti-helminth (GILL,
1992; IWU, 1993). Therefore, this study evaluated growth and nutrition of Khaya senegalensis subjected to dilutions of swine wastewater and freshwater.

\section{MATERIAL AND METHODS}

The experiment was done from August to December 2014 in a gable shade house of 50\% sombrite, in the town of Bom Jesus, Piauí, at $09^{\circ} 04^{\prime}$ $\mathrm{S}$ and $44^{\circ} 21^{\prime} \mathrm{W}$ and an altitude of $277 \mathrm{~m}$. The climate in the region, according to Köppen's classification, is type Aw - hot and semi-humid. During the experiment, the average maximum and minimum temperatures were 34.75 and $17.94{ }^{\circ} \mathrm{C}$, with an average relative humidity of $43.17 \%$.

Swine farm wastewater (SFW) was collected from a growth and finishing swine farm. After collection, the SFW was treated in a pilotscale anaerobic sequencing batch reactor system, operated in 24-hour cycles. The treated effluent was stored in a 100-litre reservoir. Chemical characterisation of the SFW was done as per the methodology described in Alcarde (2009), with the results shown in Table 1.

Table 1. Chemical characterisation of the swine farm wastewater used in the production of African mahogany (Khaya senegalensis) seedlings.

\begin{tabular}{|c|c|c|c|c|c|c|c|c|}
\hline $\mathrm{pH}$ & $\begin{array}{l}\mathrm{EC} \\
\mathrm{mS} \mathrm{cm} \mathrm{cm}^{-1}\end{array}$ & & $\mathrm{~N}$ & $\mathrm{P}$ & $\begin{array}{c}\mathrm{K} \\
\mathrm{g} \mathrm{Kg}^{-1} \\
\end{array}$ & $\mathrm{Ca}$ & $\mathrm{Mg}$ & $S$ \\
\hline 7.25 & 4.15 & & 0.37 & 0.06 & 0.28 & 0.07 & 0.06 & 0.03 \\
\hline Co & $\mathrm{Cu}$ & $\mathrm{Mn}$ & $\begin{array}{c}\mathrm{Zn} \\
\mathrm{mg} \mathrm{Kg}{ }^{-1}\end{array}$ & $\mathrm{Fe}$ & Mo & $\mathrm{Pb}$ & $\mathrm{Cd}$ & $\mathrm{Na}$ \\
\hline 0.01 & 0.01 & 0.52 & 0.30 & 3.07 & 0.01 & 0.01 & 0.02 & 2200.0 \\
\hline
\end{tabular}

The containers $\left(\begin{array}{llllll}18 & \mathrm{x} & 27 & \mathrm{~cm} & \text { black }\end{array}\right.$ polyethylene bags) were filled with Basaplant ${ }^{\circledR}$ commercial substrate, consisting of decomposed pine bark, peat, coal and vermiculite. The characteristics of the substrate before setting up the experiment were: average $\mathrm{pH}$ of $5.8 ; \mathrm{N}, \mathrm{P}, \mathrm{K}, \mathrm{Ca}$, $\mathrm{Mg}$, and $\mathrm{S}$ content of 7.0, 4.6, 2.2, 6.0, 4.0 and $1.5 \mathrm{~g}$ $\mathrm{kg}^{-1}$ respectively; bulk density of $0.46 \mathrm{~g} \mathrm{~cm}^{-3}$ and porosity of $60.4 \%$. Once the containers were filled, they were placed in the shade house.

The seeds of Khaya senegalensis were obtained from a specialised marketing company. The batch came from Honduras under registration number 21419, and had $96 \%$ germination. The seeds were disinfested by immersion in $1 \%$ sodium hypochlorite solution for five minutes, and in water for 24 hours. Sowing was done manually, using three seeds per container.
The experiment was conducted in a randomised block design with five treatments, corresponding to the concentrations of treated SFW with well water $(\mathrm{T} 1=0 \% \mathrm{SFW}, \mathrm{T} 2=25 \% \mathrm{SFW}, \mathrm{T} 3$ $=50 \% \mathrm{SFW}, \mathrm{T} 4=75 \% \mathrm{SFW}$ and $\mathrm{T} 5=100 \% \mathrm{SFW}$ ), with eight replications.

The applied irrigation depth was determined based on the water retention capacity of the substrate as estimated in a previous trial, and was obtained from the average weight of the saturated bags and after 24 hours of free drainage. The amount of water to be replaced in each substrate was $120 \mathrm{~mL}$ per plant. Fifteen days after seed germination, the doses of SFW corresponding to each treatment were applied. The seedlings were irrigated twice a day (08:00 and 16:00). Twenty days after sowing, thinning was carried out, leaving the visually most vigorous plant in each container. 
At 100 days after sowing (DAS), the seedlings were collected (systematically) to evaluate the following variables: stem diameter (SD), with a digital calliper; height $(\mathrm{H})$, determined from the base of the stem to the apical meristem, with a millimetre rule; total chlorophyll (TC), using a chlorophyll meter; number of leaves (NL); leaf area (LA), using an LI-3100C ${ }^{\circledR}$ area meter.

At the same time, samples of the substrate were collected at the end of the experiment; these were separated per treatment, air-dried, homogenised and sent to the laboratory for chemical characterisation, as per the methodology described in Tedesco et al. (1995).

The plant material was divided into shoots and roots to determine seedling shoot and root dry weight. The roots were then washed in tap water to remove any adhered material. The samples were packed separately in paper bags and placed to dry in a forced air circulation oven at $65{ }^{\circ} \mathrm{C}$ to constant weight. Subsenquently, they were weighed on a precision balance to determine the dry weight of the leaves (LDW), stem (SDW) and roots (RDW), and the total dry weight (TDW). Biomass allocation in the leaves (LBA), stem (SBA) and roots (RBA) was calculated with these data.

The Dickson quality index (DQI) proposed by Dickson et al. (1960) was obtained with Equation 1:

\section{Equation 1}

$$
\mathrm{DQI}=\mathrm{TDW} /((\mathrm{H} / \mathrm{SD})+(\mathrm{SDW} / \mathrm{RDW}))
$$

where: TDW - total dry weight (g); H shoot height $(\mathrm{cm})$; SD - stem diameter $(\mathrm{mm})$; SDW - shoot dry shoot weight (g) and RDW - root dry weight $(\mathrm{g})$.

The dry leaves were triturated in a Willey ${ }^{\circledR}$ mill and digested in a solution of nitro-perchloric acid (Tedesco et al., 1995). The nutrients N, P, K, $\mathrm{Ca}, \mathrm{Mg}$ and $\mathrm{S}$ were then determined by atomic absorption spectrometry, using certified plant material for the standard sample.

Nutrient accumulation was calculated by multiplying the LDW by the content of each nutrient. To obtain the DRIS indices (DI), nutritional balance index (NBI) and estimates of the $\mathrm{N}, \mathrm{P}, \mathrm{K}, \mathrm{Ca}, \mathrm{Mg}$ and $\mathrm{S}$ macronutrient content (MC), the INAF Leaf Analysis Interpretation software was used (Garcia, 2013). To calculate the nutrient ratio functions, the original method proposed by Beaufils (1973) was used, with the k-factor equal to 10 ranges from the optimum levels generated from the DRIS norms.

The data were submitted to Shapiro-Wilk's test for the assumption of normality and Bartlett's test for homocedasticity. The data were then submitted to analysis of variance (ANOVA), and when significant differences were found by the Ftest at $5 \%$, the average values were submitted to polynomial regression analysis to verify the optimal concentration for each variable by the first derivative of the $\beta 0$ and $\beta 1$ estimators.

The choice of the equations considered the significance of the models, the biological significance and the coefficient of determination $\left(\mathrm{R}^{2}\right)$. The analyses were performed using the ' $\mathrm{R}$ ' $\mathrm{v}$ 3.2.0 statistical software.

\section{RESULTS AND DISCUSSION}

At the end of the experiment, a trend was observed, not only for the increase in $\mathrm{N}, \mathrm{P}$ and $\mathrm{K}$ concentrations in the substrate as the concentrations of swine farm wastewater (SFW) increased, but also in electrical conductivity, with an increase of around five times when compared to the treatment with no wastewater and the treatment with $100 \%$ wastewater for the irrigation of the African mahogany (Khaya senegalensis) seedlings (Table 2). These responses to the treatments in the chemical quality of the substrate can be explained by the greater contribution of nutrients from the increasing SFW concentrations, and also by the high electrical conductivity (EC) of the wastewater (Table 2).

An increase in the levels of $\mathrm{P}$ and $\mathrm{K}$ in the soil, and nitrogen in the leachate, were found with increasing doses of SFW when fertilising the soil for soybean cultivation (Rosa et al., 2017b). However, the above authors saw no increase in Na content or electrical conductivity (EC) of the soil, and stated that these responses resultedfrom the quality of the SFW, the high rainfall index, intensive agriculture and soil depth, making the soil salinisation process something unusual.

Nevertheless, it was observed that the substrate $\mathrm{pH}$ at the end of the experiment with the seedlings of Khaya senegalensis was inversely proportional to the applied concentrations of swine farm wastewater (SFW) (Table 2). In the literature, the application of increasing doses of SFW to the soil for the production of elephant grass did not alter soil $\mathrm{pH}$ in the first year. However, in the second year of application, there was a reduction in this attribute with increasing doses of wastewater, similar to the beginning and end of the experiment in soils cultivated with soybean (Cabral et al., 2014; Rosa et al., 2017b). Guedes et al. (2006) stated that this reduction in soil $\mathrm{pH}$, as a result of the application of SFW, occurs due to the mineralisation 
of organic compounds and the release of organic acids by the soil biota.

Table 2. Chemical characterisation of the substrate at the end of the experiment with Khaya senegalensis

\begin{tabular}{llllll}
\multicolumn{5}{c}{ seedlings and application of concentrations of swine farm wastewater (SFW). } \\
\hline $\begin{array}{l}\text { SFW } \\
(\%)\end{array}$ & $\mathrm{pH}$ & $\mathrm{N}$ & $\mathrm{P}$ & $\mathrm{K}$ & $\mathrm{EC}$ \\
\hline 0 & $\mathrm{H}_{2} \mathrm{O}$ & --1.0 & $\mathrm{mS} \mathrm{cm}^{-1}$ \\
25 & 5.8 & 5.6 & 3.4 & 1.4 & 0.24 \\
50 & 5.7 & 6.2 & 4.0 & 1.6 & 0.57 \\
75 & 5.4 & 6.0 & 4.6 & 2.0 & 0.81 \\
100 & 5.5 & 5.8 & 5.5 & 2.0 & 0.91 \\
\hline
\end{tabular}

A quadratic effect was observed for the growth in height $(\mathrm{H})$ of $K$. senegalensis (Desr.) A. Juss seedlings relative to the application of swine farm wastewater (SFW) (Figure 1a), the estimated dose of $61.36 \%$ SFW giving the greatest values for $\mathrm{H}$ (average of $38.72 \mathrm{~cm} \mathrm{plant}^{-1}$ ).
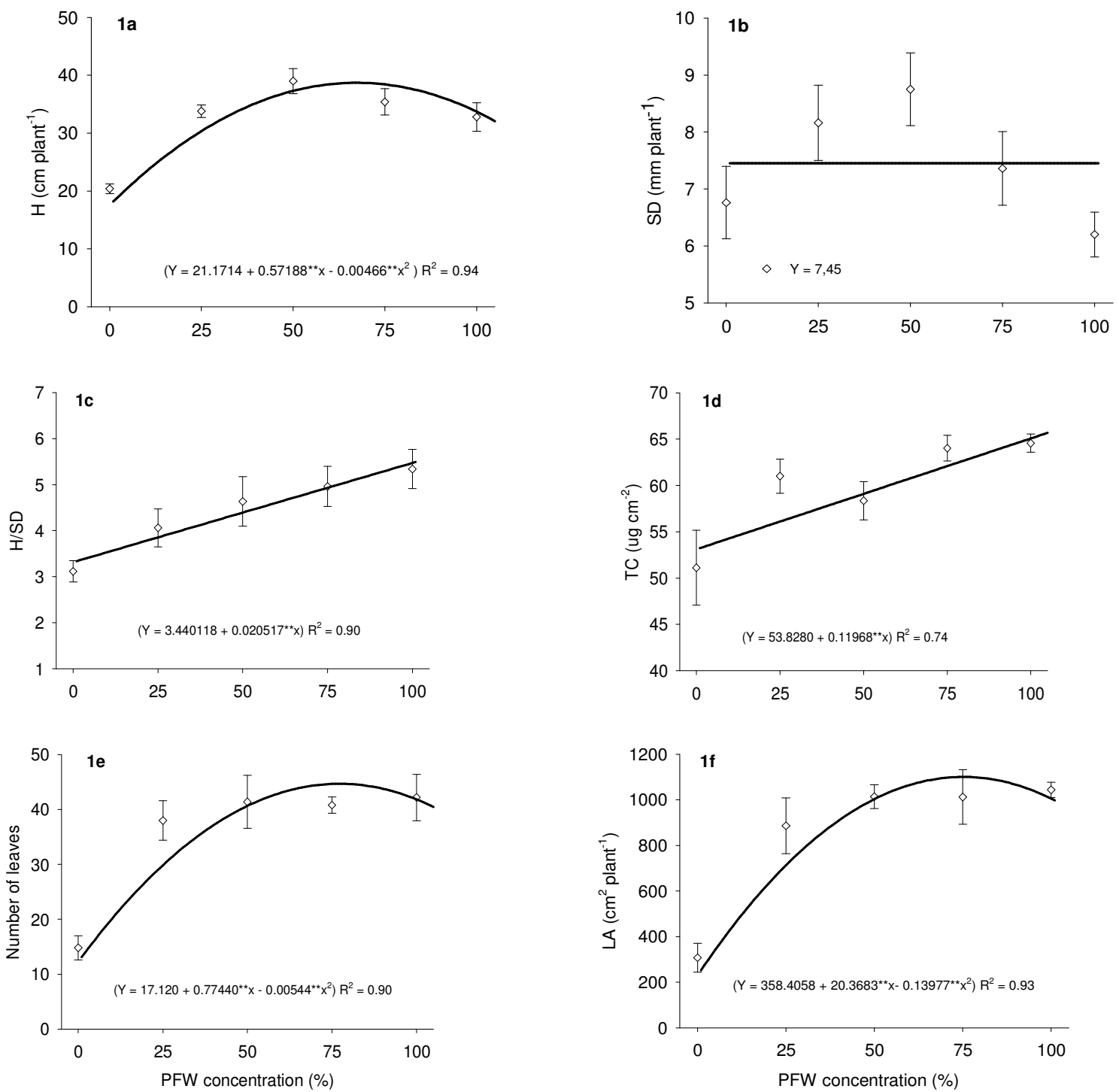

Figure 1. Height (H) (1a), stem diameter (SD) (1b), robustness index (H/SD) (1c), total chlorophyll (TC) (1d), number of leaves (NL) (1e), and leaf area (AF) (1f) in K. senegalensis (Desr.) A. Juss seedlings 100 days after sowing subjected to concentrations of swine farm wastewater (SFW). * and ** significant at 1 and $5 \%$ probability respectively. 
Height $(\mathrm{H})$ and stem diameter (SD) are characteristics used to evaluate growth and quality of tree seedlings in the nursery, and can be correlated with seedling survival and growth in the field (CARNEIRO, 1995; JACOBS et al. 2005).

Despite noting changes in stem diameter (SD) at the various points due to the application of different concentrations of SFW (Figure 1b), no adjustment of the equation gave significant coefficients at $5 \%$, the average value found was 7.45 $\mathrm{mm}$. The SD of forest seedlings is considered one of the best non-destructive indicators of seedling quality (MOREIRA; MOREIRA, 1996), and it is thought that the greater the value, the better the plant survival and growth after transplanting in the field (GOMES; PAIVA, 2004).

Among other factors, Pelissari et al. (2009) evaluated irrigation using swine farm wastewater (SFW) in the production of Eucalyptus grandis seedlings, and found that SFW had the greatest positive effect on diameter and particularly on seedling height.

Increases in the concentration of SFW applied to the $K$. senegalensis seedlings resulted in a linear increase of the H/SD index (Figure 1c), where an estimated maximum value of 5.49 was found at a concentration of $100 \%$.

A significant linear effect $(\mathrm{p} \leq 0.05)$ from SFW concentration was seen on total chlorophyll (TC) in $\mathrm{t} K$. senegalensis seedlings, with a maximum value of $65.7 \mu \mathrm{g} \mathrm{cm}^{-2}$ at a concentration of $100 \%$ (Figure 1d). The effect of the SFW concentration on the number of leaves (NL) and leaf area (LA) was best explained by the quadratic model, with maximum values of 44.67 leaves plant ${ }^{-1}$ and $1,100.45 \mathrm{~cm}^{2}$ plant $^{-1}$ at estimated concentrations of $71.1 \%$ and $72.86 \%$ SFW respectively (Figure 1e and 1f).

Irrigation at increasing concentrations of SFW in $K$. senegalensis seedlings resulted in a quadratic trend for leaf dry weight (LDW), with an optimal value for LDW of $5.93 \mathrm{~g} \mathrm{plant}^{-1}$ at an estimated concentration of $60 \%$ (Figure 2a). Root dry weight production (RDW) in $K$. senegalensis seedlings was equally distributed as a function of the increasing doses of SFW, with no significance $(p>0.05)$ between the average values (Figure $2 b$ ).

For shoot dry weight (SDW) in $K$. senegalensis seedlings, the trend for the application of SFW was quadratic (Figure 2c), with the optimal value $\left(8.31 \mathrm{~g} \mathrm{plant}^{-1}\right)$ obtained at a concentration of $58.4 \%$. This behaviour can be explained by the nutrient supply in the effluent, especially $\mathrm{N}$, which may have contributed to seedling growth during the experimental phase (Table 1). Total dry weight
(TDW) followed the trend for increase, similar to that found for NL, LDW and SDW, where the point of maximum production (11.04 $\left.\mathrm{g} \mathrm{plant}^{-1}\right)$ was seen at an estimated concentration of $54.9 \%$ (Figure 2d).

Smiderle et al. (2016), when evaluating the usage potential of adding nutrient solution for the growth and nutritional quality of $K$. senegalensis seedlings, found at 110 days $(80$ days after transplanting, and 30 days after emergence) an average value for TDW production, with and without applying a nutrient solution, of 12.75 and $11.18 \mathrm{~g} \mathrm{plant}^{-1}$ respectively, results that agree with those found in this study.

The greater the Dickson quality index (DQI) of a seedling, the better will be the balance of growth and the standard of quality, since important characteristics are weighted by the DQI in evaluating seedling quality, in addition to considering robustness and the balance of biomass distribution in the seedling (FONSECA et al., 2002; GOMES et al., 2002). However, in $K$. senegalensis seedlings, the DQI did not differ significantly ( $\mathrm{p}$ $>0.05$ ) for SFW concentration (Figure 2e).

A similar result was found in a study of SFW levels on the DQI in Eucalyptus urophylla seedlings (BATISTA et al., 2014). Nevertheless, a positive result was found from the use of swine farm wastewater in seedling growth in Corymbia citriodora at doses of 150 and $200 \%$ of the $\mathrm{N}$ requirement of the species (Coelho et al., 2017); this can be explained by the chemical composition of the treated effluents when setting up the experimental trials. The use of SFW in production of the forage turnip resulted in greater crop quality when evaluating plant height, root length, basal diameter, number of plants per area, root volume, leaf area and fresh and dry biomass weight (PEGORARO et al., 2014).

Araújo et al. (2018) found that, except for nodulation, the growth and quality of Acacia mangium Willd seedlings did not differ for the use of SFW or well water when irrigating this species, which suggests that the use of this effluent is a viable alternative for the production of quality seedlings. 

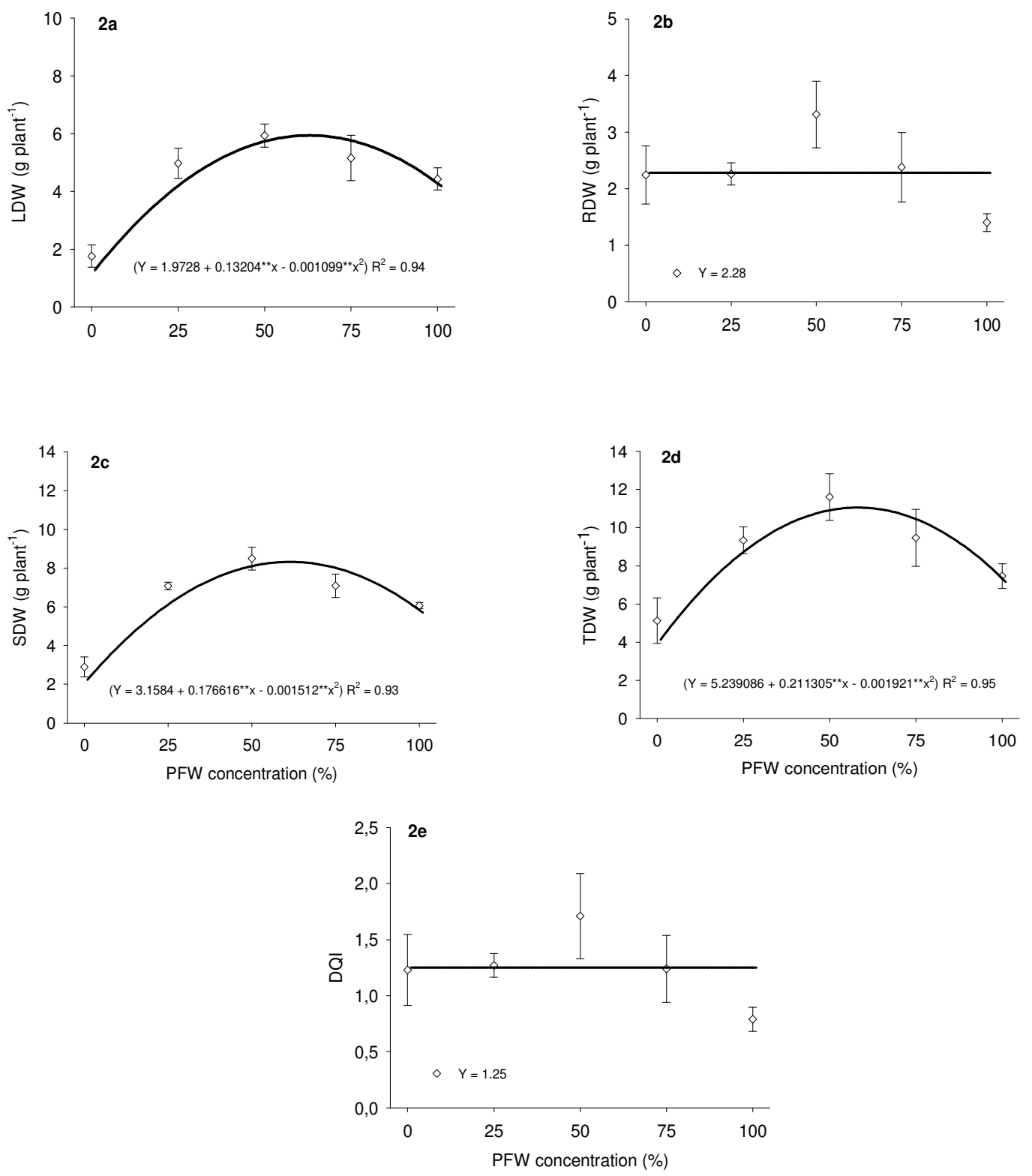

Figure 2. Leaf dry weight (LDW) (2a), root dry weight (RDW) (2b), shoot dry weight (SDW) (2c), total dry weight (TDW) (2d), and Dickson quality index (DQI) (2e) in Khaya senegalensis (Desr.) A. Juss seedlings 100 days after sowing, subjected to concentrations of swine farm wastewater (SFW). * and ** significant at 1 and $5 \%$ probability respectively.

A relative pattern of distinct biomass allocation in the plant organs can be seen in Figure 3 , where the percentage dry mass distribution in the leaves and roots was significantly affected by SFW concentration. The leaves were the main organ of accumulation, presenting an increasing linear growth trend, where the maximum value was $59.4 \%$ at a concentration of $100 \%$ (Figure 3a). Biomass allocation in the stem of $K$. senegalensis seedlings did not differ (Figure 3b); however, increases in
SFW concentration caused a linear reduction in biomass allocation in the roots (Figure 3c).

Larger concentrations negatively affect translocation and carbon storage in the root system in relation to TDW. This imbalance may be negative in terms of the adaptation and establishment of seedlings after transplanting, since the greater investment in root biomass can guarantee their survival under the adverse conditions found in the field, especially low soil fertility and seasonal water deficits, common to Brazilian tropical soils. 

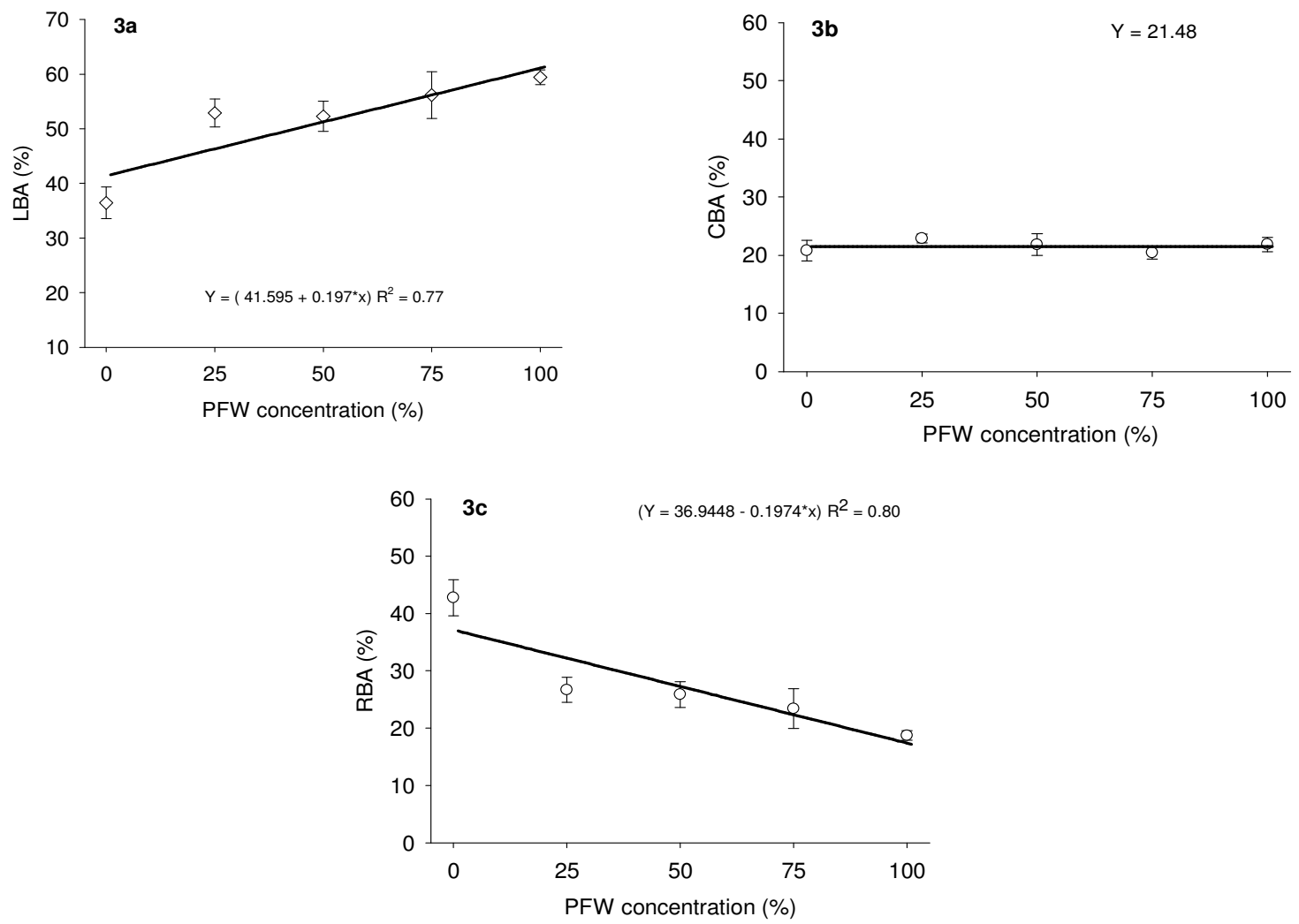

Figure 3. Allocation of biomass in leaves (3a), stem (3b), androots (3c) of Khaya senegalensis (Desr.) A. Juss seedlings 100 days after sowing, subjected to ARS concentrations. * and ** respectively significant at 1 and $5 \%$ probability.

The $\mathrm{N}, \mathrm{P}, \mathrm{K}, \mathrm{Ca}, \mathrm{Mg}$ and $\mathrm{S}$ content in the leaves of $K$. senegalensis seedlings displayed quadratic increases, with maximum values for the percentage of SFW in the irrigation water of approximately $61.2,66.9,64.6,62.6,59.5$ and $57.1 \%$ for $\mathrm{N}, \mathrm{P}, \mathrm{K}, \mathrm{Ca}, \mathrm{Mg}$ and $\mathrm{S}$ respectively, in the following order for absorption $\mathrm{N}>\mathrm{K}>\mathrm{Ca}>\mathrm{P}>\mathrm{S}>$ Mg (Figure 4). Smiderle et al. (2016) studied the growth and nutritional quality of $K$. senegalensis seedlings, after the addition of nutrient solution, favoured an increase in morphological characteristics, in addition to the total accumulation of macro- and micronutrients, with the amounts absorbed following the order: $\mathrm{N}>\mathrm{K}>\mathrm{P}>\mathrm{Ca}>\mathrm{S}>$ $\mathrm{Mg}>\mathrm{Fe}>\mathrm{B}>\mathrm{Mn}>\mathrm{Zn}>\mathrm{Cu}$.

Analysing the implications of using primary and secondary sewage effluent and water on the chemical attributes of the soil and on growth and nutritional status of $K$. senegalensis (after 6, 12 and 18 months, Ali et al. (2013) found a significant increase in nutrient content of the soil and in growth variables when irrigated with primary sewage; however, the polluting potential of SFW is far greater than that of domestic sewage.

Due to its high organic load, SFW has a biochemical oxygen demand 260 times greater than domestic sewage, which demonstrates the adaptability and rusticity of $K$. senegalensis to the planned reuse of wastewater for seedling irrigation (NOGUEIRA; SILVA, 2006).

In contrast, it can be seen that the best results for $\mathrm{H}, \mathrm{NL}, \mathrm{LA}, \mathrm{LDW}, \mathrm{SDW}$ and TDW, and for the accumulation of macronutrients in the leaves, are related to concentrations containing intermediate proportions of SFW and water. Decreases in the values of the analysed variables from the estimated optimal concentration may have occurred due to the large amount of salts in the SFW, which is characteristic of these effluents, reflecting in an increase in the EC of the substrates at the greatest concentrations of SFW (Tables 1 and 2). A similar result was found when growing soybeans, with an increase in the EC of the soil leachate that received increasing doses of SFW; this increase was undesirable due to the soluble salts (Rosa et al., 2017a). In Enterolobium contortisiliquum seedlings, Araújo et al. (2016) attributed the decrease in growth and quality of seedlings irrigated with SFW to the high concentration of ionised salts in solution causing a reduction in plant metabolism. The increasing concentrations of SFW in the 
irrigation water caused variations in the DRIS indices (Table 3).
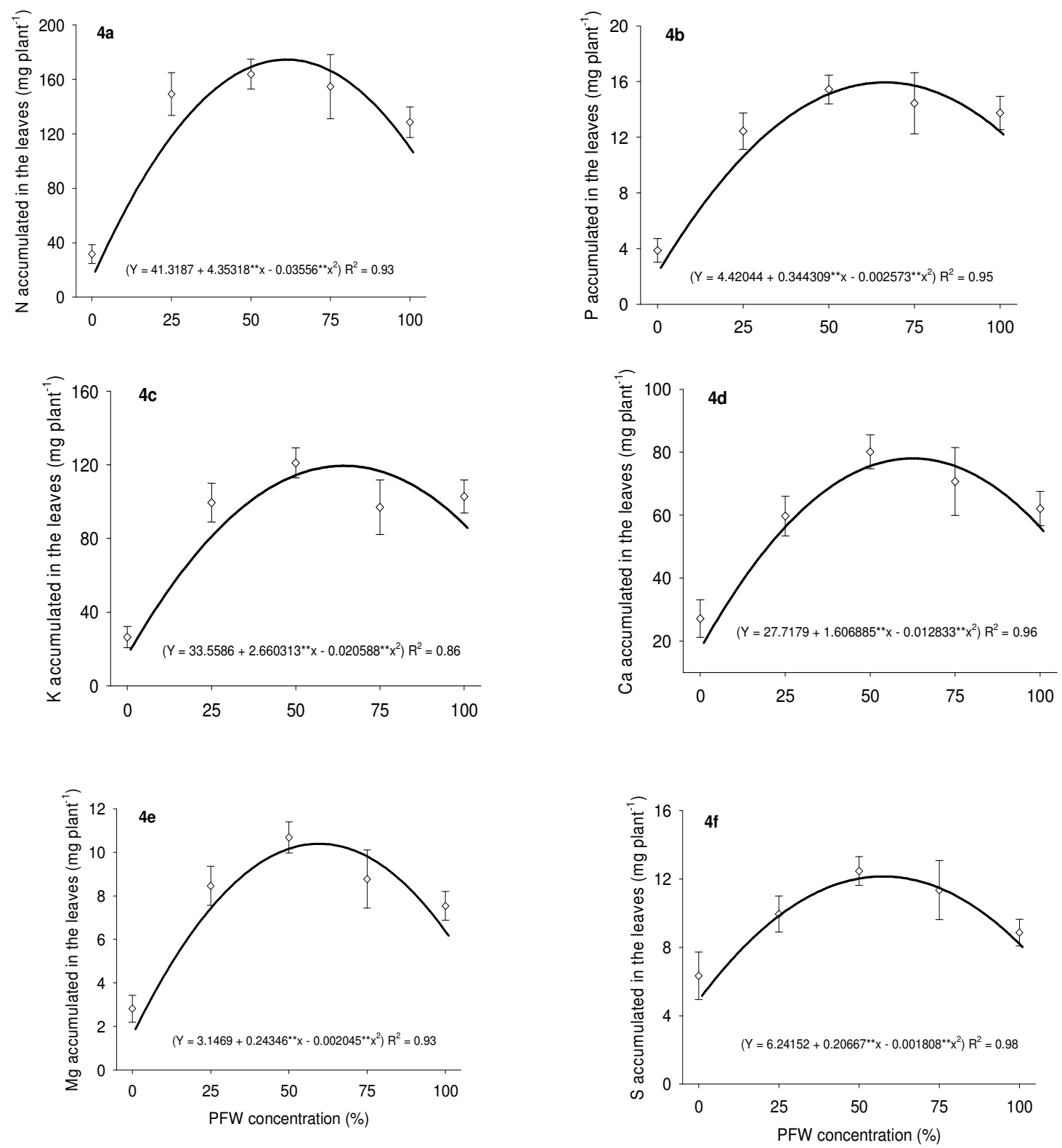

Figure 4. Nitrogen $(\mathrm{N})(3 \mathrm{a})$, phosphorus $(\mathrm{P})(3 \mathrm{~b})$, potassium $(\mathrm{K})(3 \mathrm{c})$, calcium $(\mathrm{Ca})(3 \mathrm{~d})$, magnesium $(\mathrm{Mg})(3 \mathrm{e})$ and sulphur (S) (3f) accumulated in the leaves of Khaya senegalensis (Desr.) A. Juss seedlings at 100 days after sowing subjected to concentrations of swine farm wastewater (SFW). * and ** significant at 1 and $5 \%$ probability respectively. 
Table 3. Macronutrient content in the leaves (MC), DRIS Index (DI), Average Nutritional Balance Index (NBIm) and optimal content ranges generated from the DRIS norms for seedlings of Khaya senegalensis (Desr.) A. Juss, at 100 days after sowing, for concentrations of swine farm wastewater (SFW).

\begin{tabular}{|c|c|c|c|c|c|c|c|c|}
\hline \multicolumn{2}{|c|}{$\begin{array}{l}\text { SFW } \\
(\%)\end{array}$} & $\mathrm{N}$ & $\mathrm{P}$ & $\begin{array}{l}\mathrm{K} \\
\mathrm{g} \mathrm{kg}^{-1}\end{array}$ & $\mathrm{Ca}$ & $\mathrm{Mg}$ & $\mathrm{S}$ & NBIm \\
\hline \multirow{2}{*}{0} & $\mathrm{MC}$ & 18.0 & 2.2 & 15.0 & 15.4 & 1.6 & 3.6 & \multirow{2}{*}{106.44} \\
\hline & DI & -98.82 & -160.66 & -50.84 & 31.35 & -9.00 & 287.97 & \\
\hline \multirow{2}{*}{25} & $\mathrm{MC}$ & 30.0 & 2.5 & 20.0 & 12.0 & 1.7 & 2.0 & \multirow{2}{*}{5.50} \\
\hline & DI & 8.90 & -3.63 & 6.97 & -10.34 & 0.63 & -2.54 & \\
\hline \multirow{2}{*}{50} & $\mathrm{MC}$ & 27.6 & 2.6 & 20.4 & 13.5 & 1.8 & 2.1 & \multirow{2}{*}{5.06} \\
\hline & DI & -9.24 & -5.20 & 3.82 & 5.84 & 5.52 & -0.74 & \\
\hline \multirow{2}{*}{75} & $\mathrm{MC}$ & 30.0 & 2.8 & 18.8 & 13.7 & 1.7 & 2.2 & \multirow{2}{*}{5.47} \\
\hline & DI & 1.24 & 8.48 & -10.39 & 3.90 & -6.02 & 2.79 & \\
\hline \multirow{2}{*}{100} & $\mathrm{MC}$ & 29.0 & 3.1 & 23.2 & 14.0 & 1.7 & 2.0 & \multirow{3}{*}{26.39} \\
\hline & DI & -9.62 & 49.59 & 24.78 & 4.79 & -20.44 & -49.10 & \\
\hline \multicolumn{2}{|c|}{ Optimal range } & $28.6-30.1$ & $2.7-2.75$ & $19.3-20.7$ & $12.6-13.6$ & $1.7-1.75$ & $2.10-2.17$ & \\
\hline
\end{tabular}

The average Nutritional Balance Index (NBIm), which is the modulus of the sum of the DRIS indices divided by the number of nutrients involved, allows the nutritional balance of the plants to be compared. In theory, NBI values close to zero are indicators of well-nourished plants with potentially higher production, as long as the other factors are not found to be limiting (URANO et al., 2006). Thus it was found that seedlings of $K$. senegalensis irrigated with intermediate concentrations of SFW, displayed greater nutritional balance compared to those with no SFW (Table 3).

\section{CONCLUSIONS}

The growth and nutrition of seedlings of Khaya senegalensis 100 days after sowing are significantly influenced by the application of concentrations of swine farm wastewater (SFW).

A concentration of $50 \%$ generally promoted the best results for obtaining quality seedlings among the concentrations tested.

\section{ACKNOWLEDGEMENTS}

The authors wish to thank the Support Foundation for Research of the State of Piauí, FAPEPI, for funding this study.

RESUMO: Este trabalho foi realizado com o objetivo de avaliar a utilização da água residuária da suinocultura no crescimento e no balanço nutricional de mudas de Khaya senegalensis (Desr.) A. Juss. (mognoafricano). O experimento foi instalado no Campus Prof ${ }^{a}$. Cinobelina Elvas, Universidade Federal do Piaú, em Bom Jesus, PI, dentro de uma casa de sombra. O experimento foi implantado em delineamento inteiramente casualizado, com cinco concentrações de água residuária de suinocultura (ARS) $(0 ; 25 ; 50 ; 75$ e 100\%) na água de irrigação. $\mathrm{O}$ crescimento e balanço nutricional das mudas foram avaliados aos 100 dias após a semeadura, com a mensuração da altura da parte aérea $(\mathrm{H})$, diâmetro do coleto (DC), número de folhas (NF), clorofila total (CT), área foliar (AF), massa seca da parte aérea (MSPA) e do sistema radicular (MSR) e calculadas a massa seca total (MST), as alocações de biomassa foliar (ABF), caule (ABC), raízes (ABR), o Índice de Qualidade de Dickson (IQD) e Índice de Balanço Nutricional médio (IBNm). Constatou-se que a as mudas de $K$. senegalensis responderam à ARS, apresentando os melhores resultados de crescimento e equilíbrio nutricional em concentrações em torno de 50\%. DRIS.

PALAVRAS-CHAVES: Dejetos suínos. Mogno-africano. Alocação de biomassa. Madeira nobre.

\section{REFERENCES}

ALCARDE, J. C Manual de análise de fertilizantes. Piracicaba: FEALQ, 2009. 259p. 
ALI HM, SIDDIQUI MH, KHAMIS MH, HASSAN FA, SALEM MZ, EL-MAHROUK ESM.Performance of forest tree Khaya senegalensis (Desr.) A. Juss. under sewage effluent irrigation. Ecological Engineering 61(A):117-126, 2013. DOI: https://doi.org/10.1016/j.ecoleng.2013.09.051.

ARAÚJO, E. F., ARAUCO, A. M. D. S., DIAS, B. A. S., SILVA, G. C. D., NÓBREGA, R. S. A. Substrates of Mauritia flexuosa and wastewater from pig farming on growth and quality in seedlings of Acacia mangium. Revista Ciência Agronômica, v. 49, n. 2, p. 298-306, 2018. https://doi.org/10.5935/18066690.20180034

ARAÚJO, E. F., ARAUCO, A. M.S, JESÚS LACERDA, J. J., RATKE, R. F., MEDEIROS, J. C. Crescimento e balanço nutricional de mudas de Enterolobium contortsiliquum com aplicação de substratos orgânicos e água residuária. Pesquisa Florestal Brasileira, v. 36, n. 86, p. 169-177, 2016.

https://doi.org/10.4336/2016.pfb.36.86.1135

BATISTA, R. O; MARTINEZ, M. A; PAIVA, H. N; BATISTA, R. O; CECON, P. R. O. Efeito da água residuária da suinocultura no desenvolvimento e qualidade de mudas de Eucalyptus urophylla. Ciência Florestal 24(1):127-135, 2014. DOI: http://dx.doi.org/10.4136/ambi-agua.1122.

BEAUFILS, E. R. Diagnosis and recommendation integrated system (DRIS): A general scheme for experimentation and calibration based on principles develop from research in plant nutrition. Pietermaritzburg, University of Natal: Soil Science Bulletin, 1:132p,1973.

BROOKS, J. P, ADELI A, MCLAUGHLIN MR. Microbial ecology, bacterial pathogens, and antibiotic resistant genes in swine manure wastewater as influenced by three swine management systems. Water Research 57:96-103, 2014. DOI: http://dx.doi.org/10.1016/j.watres.2014.03.017

CABRAL JR, FREITAS PSL, REZENDE R, MUNIZ AS, BERTONHA A. Changes in chemical properties of distrophic Red Latosol as result of swine wastewater application. Revista Brasileira de Engenharia Agrícola e Ambiental 18(2):210-216, 2014. DOI: http://dx.doi.org/10.1590/S1415-43662014000200012

CARNEIRO, J. G. A. Produção e controle de qualidade de mudas florestais. Curitiba: UFPR/FUPEF; Campos: UENF, 1995. 451p.

CASTALDELLI APA, SAMPAIO SC, TESSARO D, HERRMANN DR, SORACE M. Meso e macrofauna de solo cultivado com milho e irrigado com água residuária da suinocultura. Engenharia Agrícola 35(5):905-917, 2015. DOI: http://dx.doi.org/10.1590/1809-4430

COELHO, J. A.; VIEIRA, C. R.; WEBER, O. L. S. Growth and nutrition of Corymbia citriodora seedlings using doses of liquid swine waste. Comunicata Scientiae, v. 8, n. 2, p. 256-264, 2017.

https://doi.org/10.14295/cs.v8i2.1851

DICKSON A, LEAF AL, HOSNER JF. Quality appraisal of white spruce and white pine seedling stock in nurseries. The Forestry Chronicle 36(1):10-13,1960. DOI: https://doi.org/10.5558/tfc36010-1

FALODUN, A; OBASUYI, O. Phytochemical screening and evaluation of stem bark extract of Khaya senegalensis (Meliaceae) on methicillin resistant Staphyloccocus areus. Canadian Journal of Pure \& Applied Sciences. v. 3, n. 3, p. 925-928, 2009.

FONSECA EP, VALERI SV, MIGLIORANZA E, FONSECA NAN, COUTO L. Padrão de qualidade de mudas de Trema micrantha (L.) Blume produzidas sob diferentes períodos de sombreamento. Revista Árvore 26(4):515-523, 2002. DOI: http://dx.doi.org/10.1590/S0100-67622002000400015

GARCIA M. B. INAF: software para interpretação de análise foliar. 2013. 93 f. Dissertação (Mestrado Ciência do Solo) - Universidade Federal de Larvas, Mato Grosso. 
GILL LS. Ethnomedical Uses of Plants in Nigeria. University of Benin Press; Benin, Nigeria: 1992.

GOMES, J. M; COUTO. L; LEITE, H. G; XAVIER, A; GARCIA, S. L. R. Parâmetros morfológicos na avaliação da qualidade de mudas de Eucalyptus grandis. Revista Árvore 26(6):655-664,2002.

DOI: http://dx.doi.org/10.1590/S0100-67622002000600002

GOMES, J. M.; PAIVA, H. N. Viveiros florestais: propagação sexuada. Viçosa: UFV, 2004. 116p.

GÓMEZ-GARRIDO M; MARTÍNEZ-MARTÍNEZ S; FAZ CANO Á; BÜYÜKKILIF-YANARDAG A;

AROCENA JM. Soil fertility status and nutrients provided to spring barley (Hordeum distichon L.) by pig slurry. Chilean journal of agricultural research 74(1):73-82. 2014. DOI: http://dx.doi.org/10.4067/S071858392014000100012

GONÇALVES JLM, SANTARELLI EG, MORAES NETO SP, MANARA MP. Produção de mudas de espécies nativas: substrato, nutrição, sombreamento e fertilização. In: Gonçalves JLM, Benedetti V (Eds.).

Nutrição e fertilização florestal. Piracicaba: IPEF. p.309-350,2000.

GUEDES MC, ANDRADE CA, POGIANNI F, MATIAZZO ME. Propriedades químicas do solo e nutrição do eucalipto em função da aplicação do lodo de esgoto. Revista Brasileira de Ciência do Solo 30:267-280, 2006. DOI: http://dx.doi.org/10.1590/S0100-06832006000200008

IDU, M; ERHABOR, J.O.; OSHOMOH, E.O.; OVUAKPORIE-UVO, P.O. Phytochemical Composition and Antimicrobial Properties of the Seeds of Khaya senegalensis (Desc.) A. Juss. Journal of Advanced Botany and Zoology, V.1, I.4, 2014. DOI: 10.15297/JABZ.V.1, I.4.

IWU M. Hankbook of African Medicinal Plants, Pharmacognostical Profile of Selected Medicinal Plants. CRC Press Inc; Boca Raton, USA: 1993.

JACOBS, D.F.; SALIFU, K.F.; SEIFERT, J.R. Relative contribution of initial root and shoot morphology in predicting field performance of hardwood seedlings. New Forests, v.30, p.235-251, 2005.

https://doi.org/10.1007/s11056-005-5419-y

KAYSER, O.; ABREU, PM. Antileishmania and immunostimulating activities of two dimeric proanthocyanidins from Khaya senegalensis. Pharmaceutical Biology.39(4):284-8,2001. https://doi.org/10.1076/phbi.39.4.284.5921.

KOLAWOLE OT; KOLAWOLE SO; AYANKUNLE AA; OLANIRAN OI. Anti-hyperglycemic effect of Khaya senegalensis stem bark aqueous extract in Wistar rats. European Journal of Medicinal Plants 2(1):6673, 2012. https://doi.org/10.9734/EJMP/2012/934.

LAMPRECHT, H. Silvicultura nos trópicos: ecossistemas florestais e respectivas espécies arbóreas possibilidades e métodos de aproveitamento sustentado. GTZ, 1990, 343p.

MOREIRA, F.M.S.; MOREIRA, F.W. Características da germinação de sementes de 64 espécies de leguminosas florestais nativas da Amazônia, em condições de viveiro. Acta Amazonica, Manaus, v. 26, n. 1-2, p. 3-15, June 1996. DOI: http://dx.doi.org/10.1590/1809-43921996261016.

MOURA, AC.; SAMPAIO, SC.; REMOR, MB.; SILVA, AP.; PEREIRA, PAM. Long-term effects of swine wastewater and mineral fertilizer association on soil microbiota. Engenharia Agrícola 36(2):318-328, 2016. DOI: http://dx.doi.org/10.1590/1809-4430-Eng.Agric.v36n2p318-328/2016

NOGUEIRA, CCP.; SILVA IJO. Aplicação de águas residuárias da suinocultura na irrigação. Thesis 6(2):1829,2006 . 
OLIVEIRA, DMS.; LIMA, RP.; VERBURG, EEJ. Qualidade física do solo sob diferentes sistemas de manejo e aplicação de dejeto líquido suíno. Revista Brasileira de Engenharia Agrícola e Ambiental 19(3):280-285, 2015. DOI: http://dx.doi.org/10.1590/1807-1929/agriambi.v19n3p280-285

PACHECO, FP.; NÓBREGA, LHP.; TONINI, M.; SPIASSI, A.; ROSA, DM.; CRUZ-SILVA CTA. Physical attributes of soil after swine wastewater application as cover fertilizer on maize crop and black oats sequence. Revista Caatinga 30(4):955-962, 2017. https://doi.org/10.1590/1983-21252017v30n416rc

PASSARIN, OM.; SAMPAIO, SC.; ROSA, DM.; REIS, RR.; CORREA, MM. Soybean nutritional status and seed physiological quality with swine wastewater. Revista Brasileira de Engenharia Agrícola e Ambiental 20(1):16-21, 2016. DOI: http://dx.doi.org/10.1590/1807-1929/agriambi.v20n1p16-21

PELISSARI, R. A. Z.; SAMPAIO, S. C.; GOMES, S.D.; CREPALLI, M. DA S. Lodo têxtil e água residuária da suinocultura na produção de mudas de Eucalyptus grandis (W, Hill ex Maiden). Engenharia Agrícola, Jaboticabal, v.29, n.2, p.288-300, 2009. DOI: http://dx.doi.org/10.1590/S0100-69162009000200012.

PEREIRA, PAM.; SAMPAIO, SC.; REIS, RR.; ROSA, DM.; CORREA, MM. Swine farm wastewater and mineral fertilization in corn cultivation. Revista Brasileira de Engenharia Agrícola e Ambiental 20(1):49-54, 2016. DOI: http://dx.doi.org/10.1590/1807-1929/agriambi.v20n1p49-54

RABADEAUX, C.; VALLETTE, L.; SIRDAARTA, J.; DAVIS, C.; COCK, I.E. An examination of the Antimicrobial and Anticancer Properties of Khaya senegalensis (Desr.) A. Juss. Bark Extracts.

Pharmacognosy Journal 9(4):504-518, 2017. DOI: 10.5530/pj.2017.4.82 https://doi.org/10.5530/pj.2017.4.82

ROSA, DM.; SAMPAIO, SC.; PEREIRA, PAM.; REIS, RR.; SBIZZARO, M. Corn fertilization using swine wastewater and soil-water environmental quality. Engenharia. Agrícola 37(4):801-810, 2017a. DOI:

http://dx.doi.org/10.1590/1809-4430-Eng.Agric.v37n4p801-810/2017

ROSA, DM.; SAMPAIO, SC.; PEREIRA, PAM.; MAULI, MM.; REIS, RR. Swine wastewater: impacts on soil, plant, and leachate. Engenharia Agrícola 37(5):928-939, 2017b. DOI:http://dx.doi.org/10.1590/18094430-Eng.Agric.v37n5p928-939/2017

SMIDERLE, O. J.; SOUZA, A. G.; CHAGAS, E. A.; SOUZA, M. A.; FAGUNDES, P. R. O. Growth and nutritional status and quality of Khaya senegalensis seedlings. Revista Ciências Agrárias, v.59, n.1, p.47-53, 2016. DOI: http://dx.doi.org/10.4322/rca.2160

TEDESCO, MJ.; GIANELLO, C.; BISSANI, CA.; BOHNEN, H.; VOLWKWEISS, SJ. Analysis of soil, plants and other materials. Technical bulletin nº5. 2nd ed. Soil Department, UFGRS: Porto Alegre, RS, 1995. (Published in potuguese)

TESSARO, D.; SAMPAIO, SC.; ALVES, LFA.; DIETER, J.; CORDOVIL, CSCMS.; VARENNES, A.; PANSERA, WA. Macrofauna of soil treated with swine wastewater combined with chemical fertilization. African Journal of Agricultural Research 8(1):86-92, 2013. DOI: http://dx.doi.org/10.5897/AJAR12.1829

URANO, EOM.; KURIHARA, CH.; MAEDA, S.; VITORINO, ACT.; GONÇALVES, MC.; MARCHETTI, ME. Avaliação do estado nutricional da soja. Pesquisa Agropecuária Brasileira 41(9):1421-1428, 2006. DOI: http://dx.doi.org/10.1590/S0100-204X2006000900011

USDA. Foreign Agricultural Statistics.2008. http://www.fas.usda.gov/currwmt.asp

USDA. Brazil: Livestock and Products Semi-annual.2015 https://www.fas.usda.gov/data/brazil-livestockand-products-semi-annual 